\title{
TRANSFORMATION PROCESSES IN THE SYSTEM OF PROVIDING ECONOMIC SECURITY OF INVESTMENT ACTIVITIES OF INDUSTRIAL ENTERPRISES
}

\author{
Nataliia Havlovska', Yevhenii Rudnichenko², Ihor Lisovskyi
}

\begin{abstract}
The article objective is identifying the main transformational processes affecting the economic security of investment activities of industrial enterprises, which are the guarantee to their long-term development and the formation of a program for the transformation of the economic security system of enterprises in order to protect investment activity from the negative impact of changes in the external and internal environment. Methodology. The research is based on analytical materials and results of the evaluation of the dynamics of world investments for 2017 and statistical information concerning direct investments from different countries of the world in Ukrainian economics. The main postulates of the institutional theory are also used to characterize institutional changes in Ukraine for detailing their impact on the economic security of the investment activity of Ukrainian industrial enterprises. Results. The research results indicate negative tendencies in the sphere of investment both for the country as a whole and for particular economic entities. This is caused by the military conflict in the East of the country and investors' distrust to the institutional component of the functioning of the domestic economy. This situation indicates the need to introduce changes in the system of economic security of domestic enterprises. Practical implications. The authors developed the program for the transformation of the economic security system of enterprises, taking into account the actual needs for ensuring the economic security of their investment activity. Value/originality. After transformations implementation, the economic security system of enterprises receives new characteristics and allows mitigating relevant threats with different efficiency level.
\end{abstract}

Key words: economic security, investment activity, transformations, institutions.

JEL Classification: B41, D21, H56, M21, P40

\section{Introduction}

The technological backwardness of domestic industrial enterprises is the issue for discussions of domestic and foreign specialists for a long time. Among the main ways out of a crisis, most of them require the attraction of investment funds of different origin. Joint investment, reinvestment, state support are the most commonly used terms for describing the current state of investment activity of most industrial enterprises. However, the socio-economic and political processes that are taking place in Ukraine significantly limit the investors' interest in investing in industrial enterprises. At the same time, for many economic entities, the problem of ensuring the economic security of investment activity is acute as a result of imperfect legislation, opaque fiscal policy, the specifics of the courts' work and the raids intensification. Therefore, the research topic is relevant and purposeful, especially considering the importance of industrial enterprises for economic development and state budget filling.

Investment activity is accompanied by a significant number of threats and risks, which are transforming according to the situation in the markets and changes in the socio-economic environment of economic entities. Accordingly, there is a need to improve the economic security of economic entities and form new approaches for ensuring the economic security of their investment activities.

The problem of economic security of domestic enterprises and the investment development is

\footnotetext{
Corresponding author:

${ }^{1}$ Khmelnytskyi National University, Ukraine.

E-mail: nataligavlovska@gmail.com

ORCID: https://orcid.org/0000-0003-1084-2853

${ }^{2}$ Khmelnytskyi National University, Ukraine.

E-mail: e.m.rudnichenko@gmail.com

ORCID: https://orcid.org/0000-0002-9407-2026

${ }^{3}$ Khmelnytskyi National University, Ukraine.

E-mail: lisov75@ukr.net

ORCID: https://orcid.org/0000-0002-0923-0983
} 
investigated in the works by (Vasyltsiv, 2008), (Kyrylenko, 2005), (Stadnyk, 2008), (Voinarenko, 2016 ) et al. However, the security of investment activities of business entities is highlighted fragmentally and requires in-depth studies, taking into account the current trends in the economic functioning. The methodological basis of work is the empirical research of investment activity in terms of different countries and the Ukrainian economy in particular. Also, the postulates of the institutional theory are applied, which can justify the behaviour of individual subjects at the macro and micro levels. In this case, the works of such specialists as (Furubotn, 1998), (Hamilton, 1986), (Williamson, 1985) are studied.

\section{Characteristics of modern investment trends}

Realities of the present lead to the necessity of the transformation of the economic security system of domestic enterprises both in general and within certain spheres and activities. Investment activity is extremely important from the standpoint of enterprise development and the preservation of assets ownership, which requires the development of new approaches to ensuring the economic security of such activities through transformation processes in the enterprise management system as a whole and various functional areas in particular.

Investment priorities in terms of the world leading countries show investors' interest in highly profitable projects, in spite of a rather high-risk level. For a long time, the constant search for competitive advantages forced investors to invest in emerging economies and to choose business partners for their own business development among them, but in 2017, these trends slightly changed. Today the leaders in attracting foreign investment (Figure 1) are the United States, China, Hong Kong, Brazil, Singapore, and the Netherlands.

These trends are conditioned by the favourable business climate in these countries and the persistent positive trends in the development of various spheres of economic activity.

\section{Investment activity and domestic economic security}

Regarding the state of the domestic economy and the inflow of foreign direct investment, it is necessary to state mainly the negative tendencies associated with the military conflict in the East of the country and the distrust of foreign investors to the reforms declared in 2014. However, first of all, this situation is related to the military conflict within the state and the distrust of investors to business security. Today, the security issue is extremely relevant for Ukraine, because, according to the rating agencies surveys, the security level in society and the internal and external conflicts level in our state are characterized as "dangerous." Thus, the most well-known rating and the comparison of the most dangerous and safe countries in the world include the ranking of the world countries according to the Global Peace Index.

The Global Peace Index is a comprehensive indicator, which characterizes the peacefulness of the world countries, measures the level of domestic violence and the level of its foreign policy aggression. The Global Peace Index shows, which countries can be considered the most secure (and vice versa - dangerous) for human life. It is calculated according to the methodology of The Economist Intelligence Unit organization

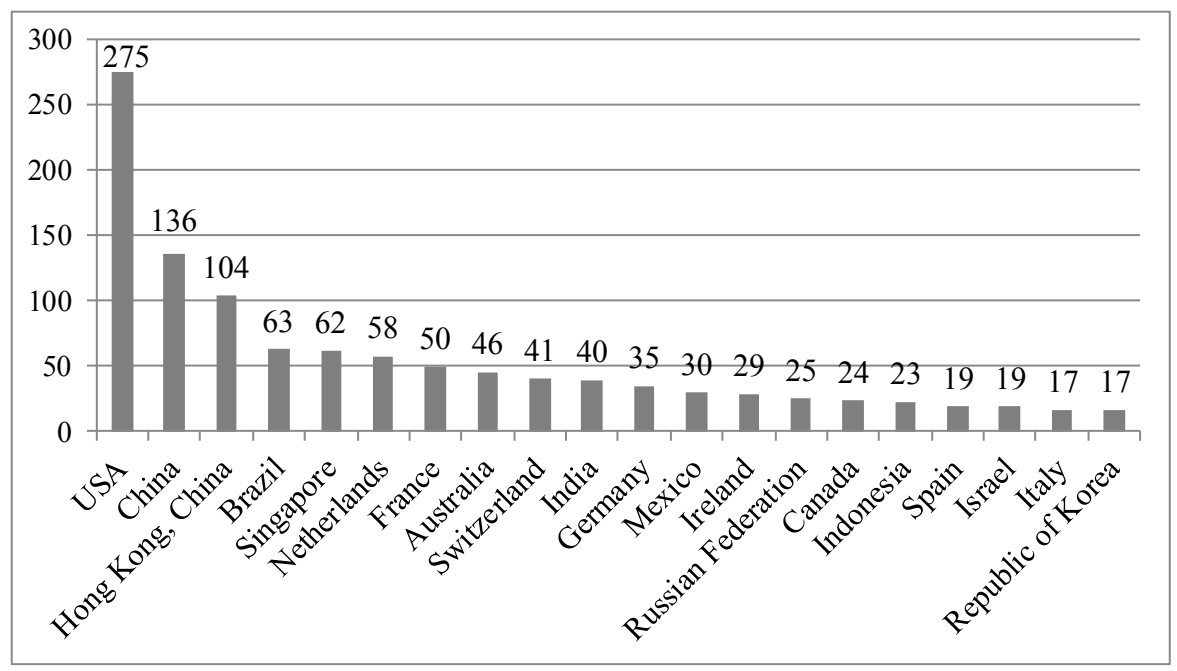

Figure 1. The inflow of foreign direct investment in 20 largest recipient countries in 2017, billion US dollars

Source: developed by the authors on the basis of (World Investment Report 2018. Investment and New Industrial Policies, p. 4) 


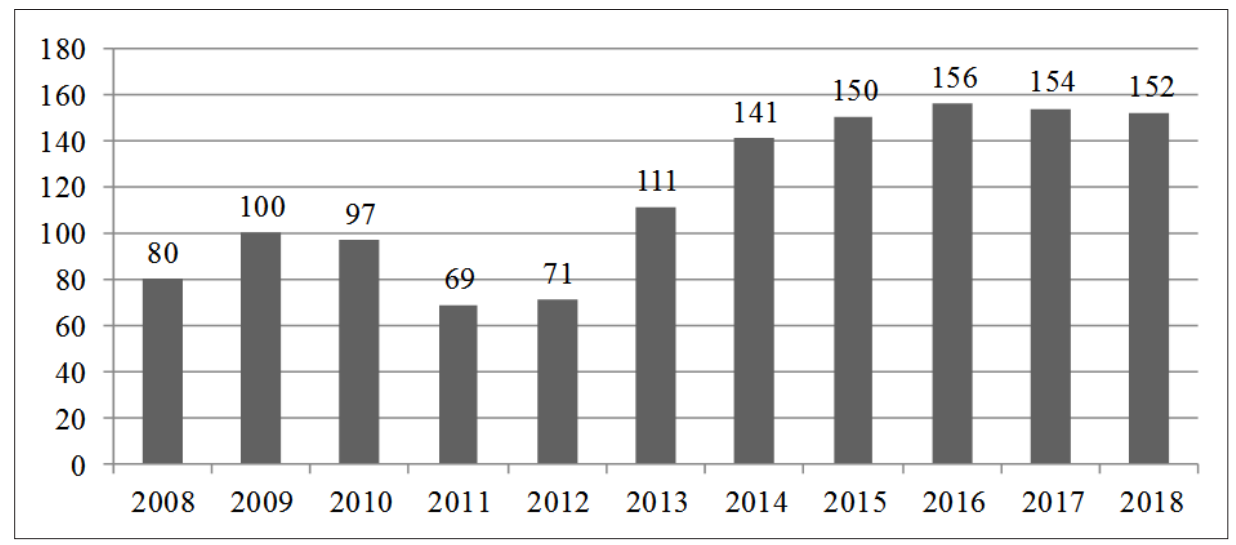

Figure 2. The rating of Ukraine among the countries according to the Global Peace Index for 2008-2018

Source: developed by the authors on the basis of (Institute for Economics \& Peace (2014-2018) Global Peace Index)

(analytical unit of the British magazine Economist). Global Peace Index is assessed on the basis of 23 criteria, divided into three categories: 1) the level of social security; 2) the dimensions of ongoing internal and international conflicts; 3 ) the level of militarization. The countries are ranked in points from 1 to 5 for each group of indicators. The less the points, the more peaceful the country is according to this criterion.

The rating of Ukraine among the countries according to the Global Peace Index for 2008-2018 is shown in Figure 2.

In 2018, according to the Global Peace Index, Ukraine ranked 152nd among 163 countries of the world and is between Pakistan and Sudan. In addition, our country has entered the list of countries that suffered the most radical deterioration of the peace compared to 2008 (with such countries as Syria, Mexico, and Egypt).

Table 1 analysis allows us to draw conclusions on the improvement of the Global Peace Index in 2018 compared with 2017 by 2 positions. The upgrade in the rating occurred despite the formalization of the trade blockade against the Donbas in March 2017, which led to an increase in internal conflicts in the state and the increase in political instability before the elections in 2019. Among the positive breakthroughs, the experts noted some successes in combating external conflicts, the consequences of terrorism and the successes in dealing with forced migrants, although this did not affect the dynamics of investment attraction significantly.

It is significant that the main source of investment for Ukrainian enterprises (Figure 3) is the Russian Federation, offshore zones (Cyprus and others), which indicates the return of domestic capital in the form of foreign investment in the country's economy but with a completely different level of protection. That is, for a long time, the taxation optimization and protection of invested capital remain the determining factors of influence on investments dynamics for Ukrainian business. However, not all domestic enterprises can operate with significant amounts of money and are able to create companies in offshore zones, while it's also necessary to take into account the dubious legality of such actions from the position of state legislation.

Therefore, the protection of investment and investment activity from the negative impact of the external and internal environment is one of the priorities for most enterprises. It is an effective system

Table 1

Dynamics of the Global Peace Index rating estimation for 2014-2018

\begin{tabular}{|c|c|c|c|c|c|c|c|c|c|c|c|}
\hline \multirow{2}{*}{\multicolumn{2}{|c|}{ iteria }} & \multicolumn{2}{|c|}{$\begin{array}{c}2014 \\
(162 \text { countries })\end{array}$} & \multicolumn{2}{|c|}{$\begin{array}{c}2015 \\
(162 \text { countries })\end{array}$} & \multicolumn{2}{|c|}{$\begin{array}{c}2016 \\
(163 \text { countries })\end{array}$} & \multicolumn{2}{|c|}{$\begin{array}{c}2017 \\
(163 \text { countries })\end{array}$} & \multicolumn{2}{|c|}{$\begin{array}{c}2018 \\
(163 \text { countries })\end{array}$} \\
\hline & & bo : & $\stackrel{\overbrace{}}{\overparen{\Xi}}$ & $\infty$ & 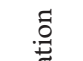 & 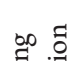 & $\stackrel{0}{\stackrel{0}{\Xi}}$ & $\infty$ & $\stackrel{0}{\stackrel{0}{\Xi}}$ & bo : & 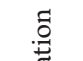 \\
\hline 1. & Level of social security & 98 & 2,529 & 145 & 3,190 & 150 & 3,384 & 148 & 3,340 & 150 & 3,328 \\
\hline 2. & $\begin{array}{l}\text { Dimensions of internal } \\
\text { and international conflicts }\end{array}$ & 157 & 3,200 & 151 & 2,830 & 156 & 3,272 & 156 & 3,218 & 159 & 3,494 \\
\hline 3. & Level of militarization & 124 & 1,986 & 126 & 1,670 & 158 & 2,810 & 152 & 2,534 & 140 & 2,272 \\
\hline & Total index value & 141 & 2,546 & 150 & 2,845 & 156 & 3,287 & 154 & 3,184 & 152 & 3,113 \\
\hline
\end{tabular}

Source: developed by the authors on the basis of (Institute for Economics \& Peace (2014-2018) Global Peace Index) 


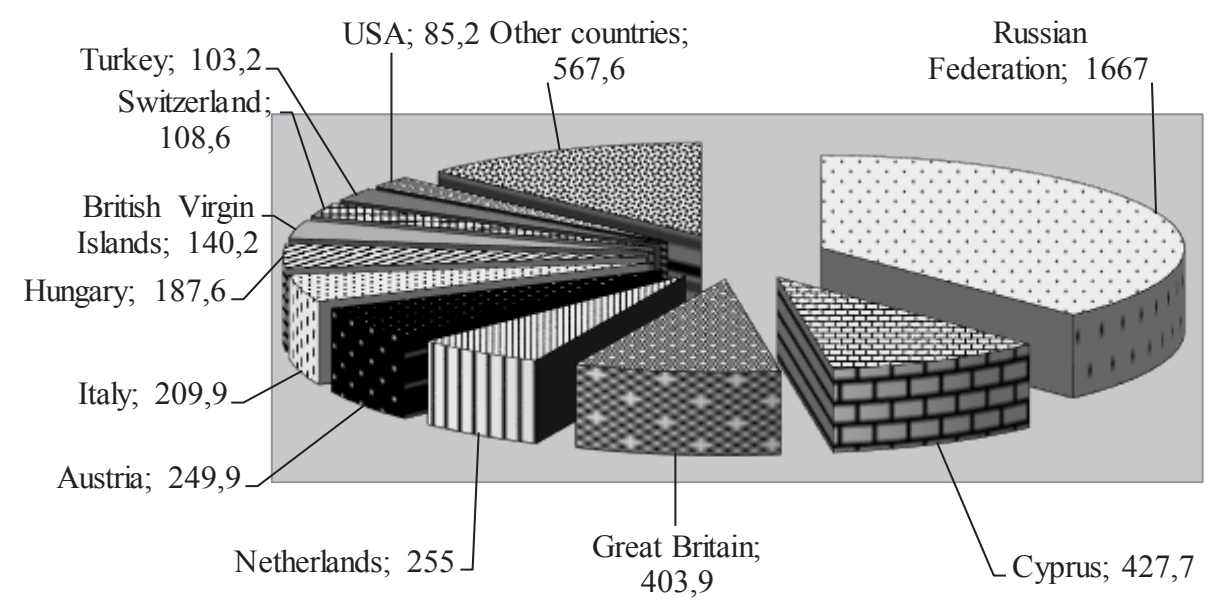

Figure 3. Direct foreign investments (share capital) from the world countries in the Ukrainian economy by the results of 2016, billion US dollars

Source: developed by the authors on the basis of (State Statistics Service of Ukraine (2016)

of economic security of enterprises that can neutralize such a negative impact and provide an adequate level of investment security in line with today's realities. As stated in (Rudnichenko Ye. M., 2018), the decisionmaking takes place in accordance with the actual and potential risks and threats of the enterprise's activity (observance of the safety criterion), the profitable activity of the enterprise taking into account the negative influence of environments is being ensured (observance of the profitability criterion) and finding the optimal correlation between the security state and the activity profit is being implemented (balance) when determining the managerial influence within such management object as enterprise economic security.

\section{Forming the transformation program of the enterprise economic security system}

It is typically that institutional changes in Ukraine take place with difficulties and hoping to solve the investors' problems only through the legislative changes is quite difficult. Therefore, at the level of each particular enterprise, the transformation program of the economic security system should be formed taking into account the actual needs for ensuring the investment activity economic security. In order to do this, it is necessary to determine general preconditions for the formation of such a program emphasizing on economic security and investment activity (Figure 4), which form the general system of economic security of investment activity.

Commenting on Figure 3, it should be emphasized that the normative activity field of business entities in Ukraine is rather developed, but the legislation observance by all market players and the possibility of protecting their rights in court is a cause for criticism by foreign investors for several years. Regarding the strategic component, it should be noted that at the level of individual enterprises, strategic aspects are considered and a certain investment strategy is formed, although not for the long term. And strategic priorities are mainly declarative at the institutional level. The investment sources definition and their protection are a priority task of management at the macro and micro level since the risk of invested capital loss is restrained by most foreign investors, while domestic ones try to protect it in different ways, despite the legality of such operations.

Personnel and material-technical support and their protection as objects of economic security involve a complex of actions directly on a concrete enterprise, taking into account its specifics and development features. And the profit distribution affects the investment sources formation and depends on the enterprise owners' policy. Regarding the status of the enterprise economic security system (EESS) and the subordination within the enterprise, it is necessary to note the significant differences in the efficiency and the accuracy of the management decisions made in the enterprise economic security system with the supersystem status and the status of the ordinary unit.

Taking into account the general features of the economic security formation in the field of investment management mentioned above, it is necessary to develop a program of transformation of the economic security system, taking into account the actual needs of ensuring the economic security of investment activity. Such a program should include a certain list of items, namely:

1. Identification of changes in the external and internal environment.

2. Identification of threats and their distribution by the degree of importance for investment activity.

3. Formation of management decisions regarding the transformation of the EESS in accordance with actual threats to investment activity. 


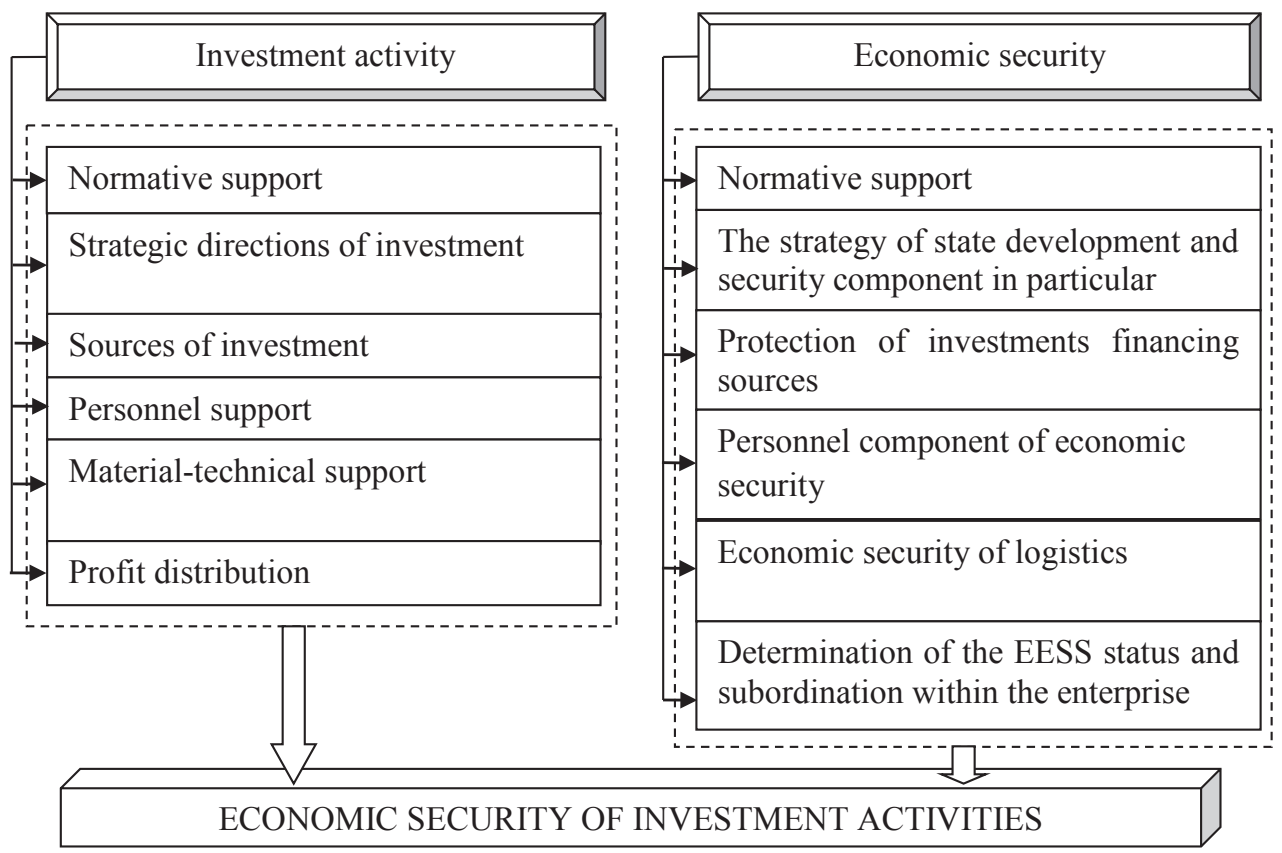

Figure 4. Prerequisites of forming a program for the transformation of the enterprise economic security system

Source: developed by the authors

4. Determination of the subjects of managerial influence, which is responsible for the transformation of the EESS.

5. Identification of objects of transformational influence within the system of economic security.

6. Instrumental provision of transformational influence.

7. Implementation of transformations of the EESS in accordance with actual threats to investment activity.

8. Evaluating the effectiveness of the EESS transformations in the context of protecting its investment activity and defining further actions.

Commenting on the above program, we note that the initiation of transformation occurs as a result of changes in the external and internal environment of the enterprise activity. At the same time, not all changes will be significant and will require an appropriate response for economic security; therefore, it is necessary to determine the immediate threats to the enterprise as a whole and to its investment activity in particular. After this stage, the significance of threats is determined and appropriate management decisions are made that directly trigger the process of implementing the transformations of the economic security system. An important stage in the transformation program is the identification of responsible persons who will make transformations and identify the range of people who will be directly involved in the processes mentioned above.

Identification of objects of transformational influence within the system of economic security will be carried out taking into account the specifics of investment activity and priority directions of enterprise development, which require adequate support. It also determines a certain set of tools that can be used for transformational influence and forms the necessary regulations for their application. After that, the implementation of the transformation of the EESS in accordance with the actual threats to investment activities takes place and their effectiveness is determined. After the transformation, the system of economic security acquires new characteristics and allows mitigating the actual threats with different levels of efficiency. As a result, the management of enterprise determines the following actions for the implementation of transformations and evaluates the prospects for further cyclical functioning of the program under study.

\section{Conclusions}

Taking into account the current trends of capital movements and the investors' interest in stable incomes, it is not worthwhile expecting a rapid growth of foreign investment in the Ukrainian economy in the near future. The results of empirical studies presented in the work give prove to this statement. According to these results, Ukraine is not in the top twenty leading countries in foreign investment and, taking into account the fall in Ukraine's rating among countries according to the Global Peace Listing Index over the past five years, it will be very difficult to regain investors' confidence.

In this regard, the main task for Ukrainian enterprises is to protect own capital and mitigate the threats and risks associated with significant turbulence of the Ukrainian 
economy and internal-organizational processes. This requires the improvement of the economic security of such enterprises due to the necessary transformations. Transformation of the enterprise economic security system can partly offset the negative impact of the external and internal environment by improving the economic security system and increasing the reaction speed of such a system to actual threats. Therefore, the program formation for the transformation of the economic security system taking into account the actual needs of ensuring the economic security of investment activity is one of the obligatory elements of the strategic development of investment activity of any enterprise. Such a program includes eight elements, starting from the identification of changes in the external and internal environment and ending with the evaluation of the effectiveness of transformations.

Considering the insufficient number of scientific and methodological approaches to the instrumental support of transformation processes and the direct improvement of the enterprise economic security system, it is necessary to carry out further research on this issue, defining effective tools for the implementation of the proposals outlined in the article.

\section{References:}

Vasyltsiv, T. H. (2008). Ekonomichna bezpeka pidpryiemnytstva Ukrainy: stratehiia ta mekhanizmy zmitsnennia [Economic Security of Ukrainian entrepreneurship: strategy and mechanisms for enhancement]. Lviv: Aral, 384 p. (in Ukrainian)

Kyrylenko, V. I. (2005). Investytsiina skladova ekonomichnoi bezpeky [Investment component of economic security]. Kyiv: KNEU, 232 p. (in Ukrainian)

Stadnyk, V. V., Rudinchenko, Ye. M., Tomal, T. S., Nepogodina, N. I. (2008). Innovatsiino-investytsiini stratehii v upravlinnia rynkovoiu vartistiu pidpryiemstva [Innovative-investment strategies in managing the market value of enterprises]. Khmelnytsky: TRIADA, 234 p. (in Ukrainian)

United Nations (2017). World Investment Report 2018. Investment and New Industrial Policies, Geneva: Printed at United Nations. Retrieved from: http://unctad.org/en/PublicationsLibrary/wir2018 en.pdf

State Statistics Service of Ukraine (2016). Priami investytsii (aktsionernyi kapital) iz krain svitu v ekonomitsi Ukrainy u 2016 rotsi [Direct investments (share capital) from the world countries in the economy of Ukraine in 2016]. Retrieved from: http://www.ukrstat.gov.ua/operativ/operativ2016/zd/ivu/ivu_u/ivu0416.html (in Ukrainian)

Rudnichenko, Ye. M., Havlovska, N. I., Yadukha, S. Y. (2018). Implementation of managerial innovations in the sys-tem of providing economic security for subjects of foreign economic activity. Scientific bulletin of Polissia, 1(13), 88-94. Retrieved from: http://nvp.stu.cn.ua/uk/component/k2/item/950-rudnichenko-ye-m-havlovska$\mathrm{n}$-i-yadukha-s-y-implementation-of-managerial-innovations-in-the-system-of-providing-economic-security-forsubjects-of-foreign-economic-activity.html

Furubotn, E., Richter, R. (1998). Institutions and Economic Theory. The Contribution of the New Institutional Economics. Ann Arbor, Michigan: The University of Michigan Press, 672 p.

Hamilton, D. (1986). Technology and institutions are neither. Journal of Economic Issues, 20(2), 525-532.

Williamson, O. E. (1985). Reflection on the new institutional economics. Journal of theoretical and institutional economics, 141(1), 187-195.

Voynarenko, M. P., Dzhedzhula, V. V., Yepifanova, I. Yu. (2016). Modeliuvannia protsesu pryiniattia rishennia shchodo dzherel finansuvannia innovatsiinoi diialnosti [Modelling the process of making decisions on sources of financing of innovation activity]. Economic Annals-XXI, 160(7-8), 126-128. Retrieved from: http://soskin.info/ userfiles/file/Economic-Annals-pdf/DOI/ea-V160-25.pdf (in Ukrainian)

Institute for Economics \& Peace (2018). Global Peace Index: Measuring Peace in a Complex World. Retrieved from: http://visionofhumanity.org/ 